WOR K I N G PAPER

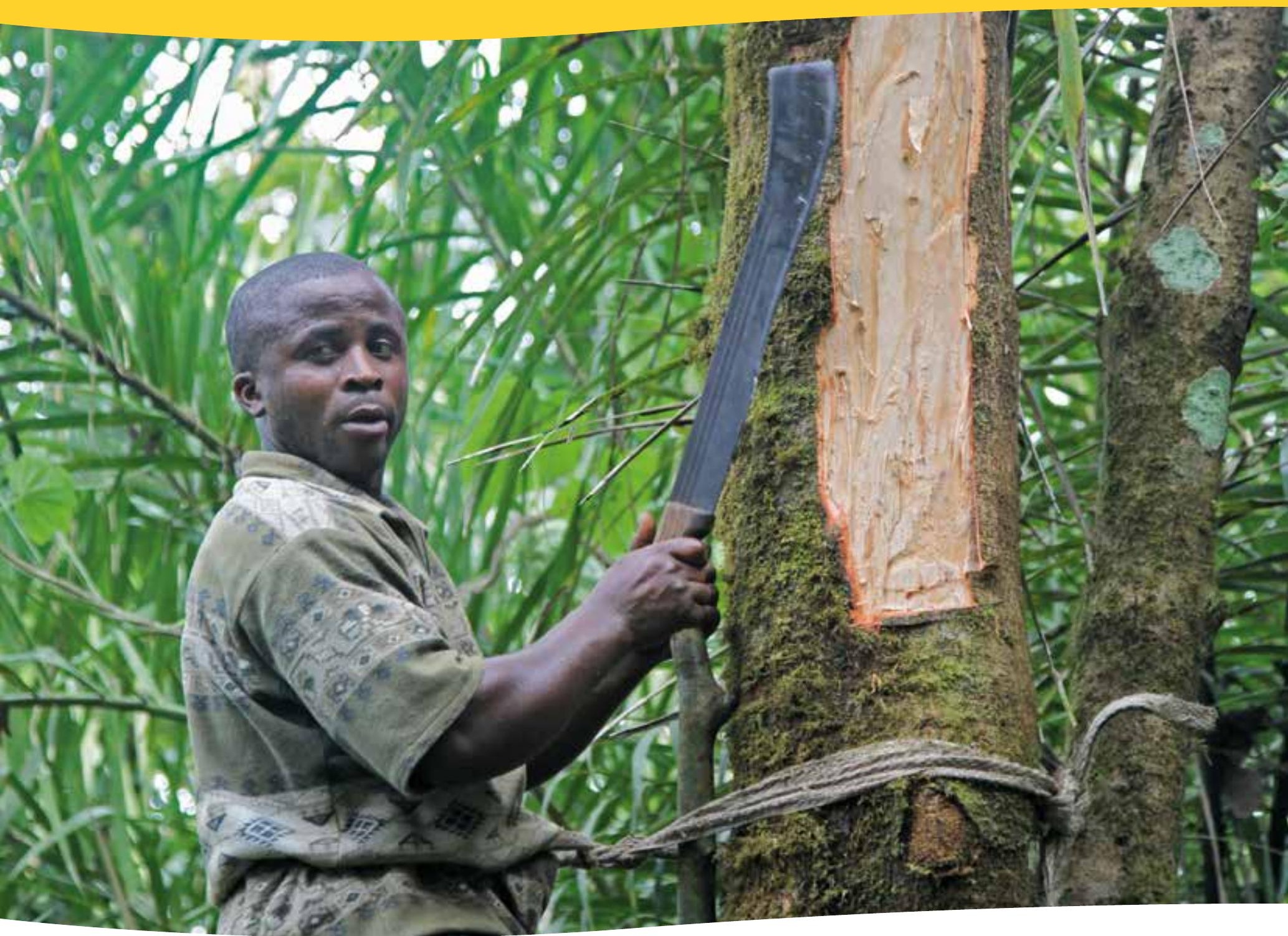

Power, profits and policy

A reality check on the Prunus africana bark trade

Anthony B. Cunningham

Marie L. Avana Tientcheu

Valentine F. Anoncho

Robert Nkuinkeu

Terry Sunderland 

Working Paper 153

\title{
Power, profits and policy
}

\section{A reality check on the Prunus africana bark trade}

\author{
Anthony B. Cunningham \\ School of Plant Biology, University of Western Australia \\ Marie L. Avana Tientcheu \\ Department of Forestry, Faculty of Agronomy and Agricultural Sciences, The University of Dschang \\ Valentine F. Anoncho \\ Mankon Bamenda \\ Robert Nkuinkeu \\ World Botanical Exchange and Services \\ Terry Sunderland \\ Centre for International Forestry Research
}


Working Paper 153

(c) 2014 Center for International Forestry Research

Content in this publication is licensed under a Creative Commons Attribution-NonCommercial-NoDerivs 3.0 Unported License http://creativecommons.org/licenses/by-nc-nd/3.0/

Cunningham AB, Avana Tientcheu M-L, Anoncho VF, Nkuinkeu R and Sunderland T. 2014. Power, profits and policy: A reality check on the Prunus africana bark trade. Working Paper 153. Bogor, Indonesia: CIFOR.

Photo by Terry Sunderland/CIFOR

\section{CIFOR}

Jl. CIFOR, Situ Gede

Bogor Barat 16115

Indonesia

$\mathrm{T}+62(251) 8622-622$

$\mathrm{F}+62$ (251) 8622-100

E cifor@cgiar.org

\section{cifor. org}

We would like to thank all donors who supported this research through their contributions to the CGIAR Fund For a list of Fund donors please see: https://www.cgiarfund.org/FundDonors

Any views expressed in this publication are those of the authors. They do not necessarily represent the views of CIFOR, the editors, the authors' institutions, the financial sponsors or the reviewers. 


\section{Table of Contents}

Acknowledgements

1 Introduction 1

2 Methods 2

3 Results $\quad 3$

3.1 'Mind the gap' 3

3.2 A green economy goes into the red 3

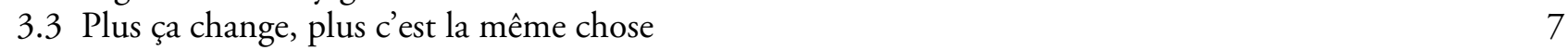

$\begin{array}{ll}3.4 \text { Back to the future: cultivating a green economy } & 11\end{array}$

4 Discussion 11

5 References $\quad 14$ 


\section{List of Figures and Tables}

\section{Figures}

Bark exports from Cameroon over 40 years

2 Bundles of illegally harvested bark at Mapanja Village, Mount Cameroon in 1993

3 Bark harvesters get paid a fraction of the FOB price paid to elite exporters

3 The more things change, the more they stay the same - Despite some diversification 7

4 Average prices paid per kg for $P$. africana bark to harvesters and "exporters" 9

5 Bark production from cultivation 11

\section{Tables}

1 Gap analysis between Rhetoric and reality 5

2 Mutiny over the bounty: Lobbying and advocacy rhetoric as a strategy to overturn the $2007 \mathrm{EU}$ ban. 8

3 Green production and red herrings: A reality check on P. africana cultivation. 10 


\section{Acknowledgements}

This study was funded as part of ongoing research by The CGIAR Research Program on Forests, Trees and Agroforestry. We would like to thank Dr. Jean Betti (ITTO-CITES) for providing updated export trade records, and Charles Kale, MOCAP Finance Manager for updated information on bark prices paid to harvesters in Mount Cameroon area. We would also like to thank Mr. Frank Stenmanns, Dr. Peguy Tchouto and their team in Cameroon; the Conservator of Mount Cameroon National Park, Simon Besong and Philip Nkeng, the Conservator of the Limbe Wildlife Centre, and Stella Asaha of FOREP, for their assistance in the field. Robert
Nkuinkeu would also like to thank the Delegation of Forestry and Wildlife (MINFOF) in Banyo and Tignere for contributing vital information for this report, as well as students of the University of Buea and the harvesters of $P$. africana of Banyo and Tignere for sharing their knowledge with the research team. Current export price data received from Joef Brinckmann was much appreciated. Finally, we are grateful to the people of Mapanja, Bova and Bokwangwo villages and many other field informants for their enthusiasm and active engagement in discussing Prunus africana and its exploitation. 



\section{Introduction}

When it comes to public attention, plants usually have a low profile compared to charismatic mammals such as pandas, rhinos and elephants. Prunus africana, the only African wild relative of peaches, plums and almonds, is an exception. In the 1990s, $P$. africana trade was discussed in British parliament, with $P$. africana becoming a "flagship" species for DFID (Page 2003). The World Agroforestry Centre (ICRAF) even suggested that just as the giant panda was a symbol for protecting endangered animals, so $P$. africana was the icon for saving threatened trees (Futureharvest 2000; Page 2003). Although $P$. africana is listed in the IUCN Red List as a vulnerable species, thousands of plant species are far more threatened (1490 critically endangered and 2239 endangered) (WCMC 1998). In addition, hundreds of African plant species are traded nationally for medicinal purposes, many far more threatened than $P$. africana (Cunningham 1991, 1993; Williams 2007). So why has P. africana become the focus of so much attention? One reason is the commercial value placed on $P$. africana bark. More wild harvested bark is internationally traded from $P$. africana than from any other species, with attention drawn to $P$. africana after a review which showed the extent of trade (Cunningham and Mbenkum 1993). A second reason is that in 2007, due to concerns about unsustainable wild harvest, the European Union (EU) instituted an import ban on P. africana bark.1 In 1995, when P. africana was added to CITES Appendix II, 2 this was a high-profile decision as most (95\%) of the $1398 \mathrm{t}$ exported from Cameroon was to Europe (mainly France [68.7\%] and Spain [26.6\%]) (MINOF 2013). In 2012, due to zero quotas granted by CITES to Burundi, Equatorial Guinea, Kenya and Madagascar, Cameroon currently supplies $72.6 \%$ of the global supply of $P$. africana bark $(658.7 \mathrm{t})$; the remainder comes from Uganda (176.2 $\mathrm{t}$ ) and Democratic Republic of Congo (DRC) (72 t), (CITES 2012).

\footnotetext{
At the 42nd Meeting of the European Union Scientific Review Group (SRG) on the 7th of December 2007.

2 This was based on the need for "Non-detriment findings" (NDF) in Article 4 of EU Regulation No. 338/97: Trade in specimens of Appendix II species may only take place if that trade is not detrimental to the survival of the species or its population in the wild. That the trade is non-detrimental has to be certified by the relevant authorities of the exporting countries and by the importing countries of the EU.
}

Since its CITES Appendix II listing in 1995, over 50 research publications and 13 postgraduate theses (the majority by Cameroonian graduates) have been produced on P. africana (Anoncho 2014; Avana 2006; Bellekwang 2006; Buchwalt 1996; Duone 2008; Ekane 2005; Ingram 2014; Ndam 1998; Nkeng 2009; Ntsama 2008; Stewart 2001; Tassé 2006; Wazinski 2001). Yet there remains a major divide between these research products and practical conservation action. Knight et al. (2008) and Habel et al. (2013) refer to this as the 'knowing-doing gap', where research results are not translated into practical management. Cameroon's National Plan for P. africana (Ingram et al. 2009) is being considered as a model for replication elsewhere, including the precedent of allowing commercial harvest within protected areas (Mount Cameroon National Park). Despite the ecological values of $P$. africana in globally significant conservation areas, including in the diet of rare and often endemic birds and primates such as red colobus (Chapman and Chapman 1999; Chapman et al. 2003) and black-and-white colobus (Fashing 2009), there is growing pressure for commercial $P$. africana harvest in the Albertine Rift. Examples of this are the inventory of $P$. africana stocks in Kibira National Park, Burundi (Betti et al. 2013) and commercial $P$. africana harvest adjacent to Kahuzi-Biega and Virunga National Parks in eastern DRC. We suggest that it is time for a reality check with regard to the wild harvest of $P$. africana. This research study therefore centers around the following four questions.

1. What can we learn from the $P$. africana case in terms of bridging the gaps between science and the practice of sustainable use and conservation?

2. How sustainable is sustainable harvest? How does P. africana compare in terms of costs vs. benefits of sustainably managed bark harvests?

3. Given that most bark commercially harvested for large-scale export for a wide range of other species has made the shift from wild harvest to on-farm production, and that thousands of Cameroonian farmers have cultivated this species since the late 1970s, why hasn't the shift to commercial trade from cultivation happened in the case of $P$. africana?

4. How have national and international policies and trade influenced the shift from over-exploitation to sustainable harvest of Prunus africana (national bans, CITES Appendix II listing and the 2007 EU ban)? 


\section{Methods}

We used several approaches in this study, combining our experience in working with $P$. africana over a 30-year period with a thorough literature review and updated trade data with "ground-truthing" in the field in 2013 and 2014. This enabled us to get a perspective on trade volumes (1991-2012), bark prices (and value-chain data) and the gaps between research reports and practice. Understanding why there is a "knowing but not doing" gap in the $P$. africana case requires scrutiny beneath the surface of national "policy theatre", where there is considerable "talking but not doing". Understanding the links between capital accumulation and political power is a key. The role of political elites is converting natural resources into political and financial capital is well-known since Sahlins' (1966) seminal study of "big men" in Melanesia and Polynesia. Two approaches provide excellent lenses for a deeper understanding of policy failure and the "knowingdoing gap" in the P. africana case. First, we took a similar approach to Médard's (1992) analyses of power, politics and African development. Second, we examined studies of commodity chains that assess the power relations that coalesce around different commodities (Ribot 1998; Ribot and Peluso 2003), similar to the approach used to study $P$. africana trade in Madagascar (Neimark 2010). In southwest Cameroon, "ground-truthing" involved fieldwork and discussions with a range of people involved with $P$. africana, including harvesters, local $P$. africana farmers, national park managers and donor-funded researchers in the Mount Cameroon area in 2014. In northwest Cameroon, one of us (VFA) conducted focused group discussions and detailed interviews with 27 resource persons. These respondents were selected from different categories of people involved in the P. africana trade (five government representatives, seven NGO administrators, ten farmers/harvesters, four heads of community forests and one bark exporter). It was clear from our literature review that most previous research had focused on ecological research, cultivation or genetic studies of P. africana. A few policy analyses have been done on P. africana trade in Cameroon (Cunningham and Cunningham 2000; Page 2003) or Madagascar (Neimark 2010), with only one desktop study (Samndong 2010) and one field study (Anoncho 2014) carried out after the 2007 EU ban on trade and release of the National Management Plan for $P$. africana in Cameroon (Ingram et al. 2009).

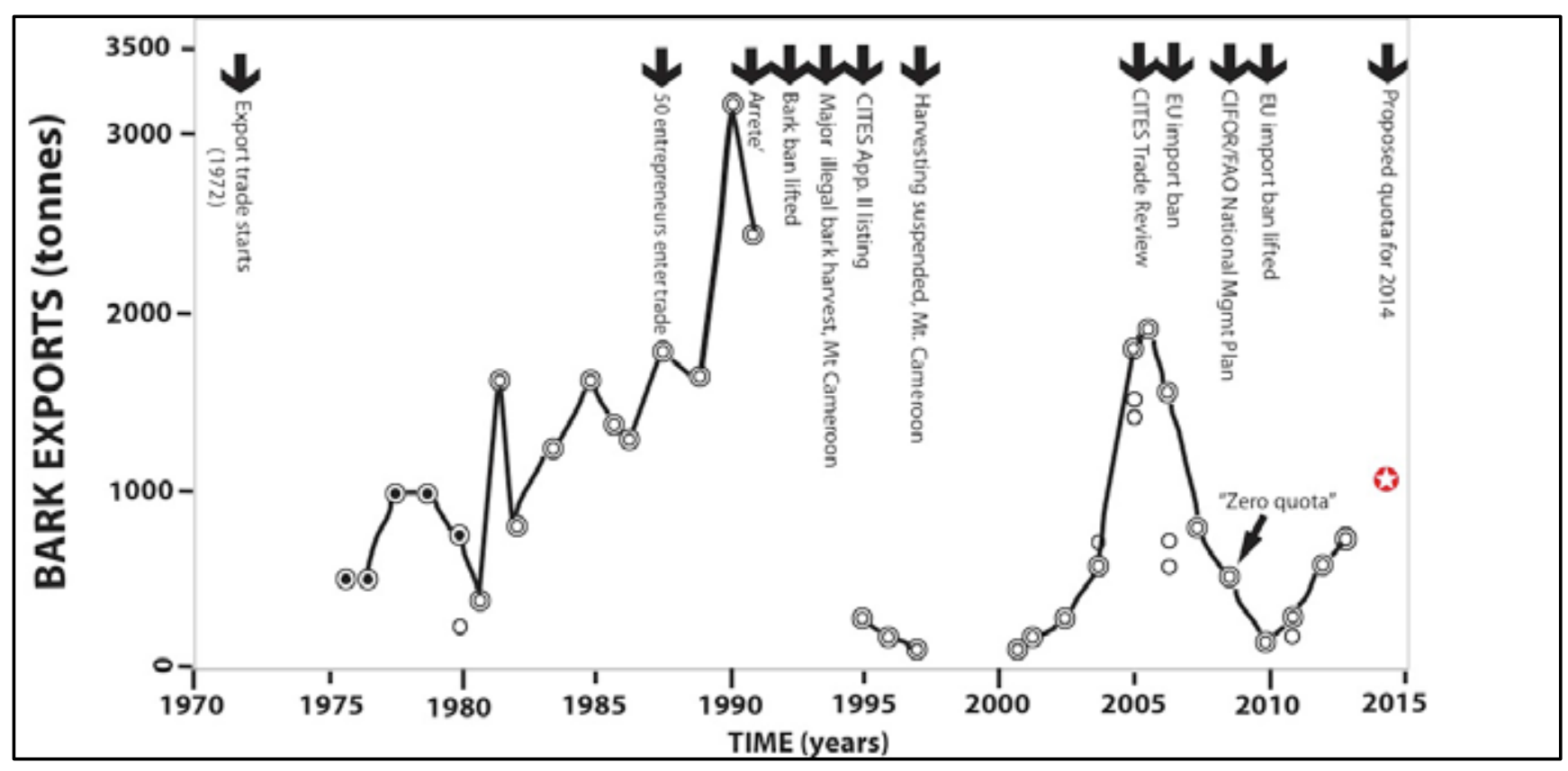

Figure 1. Bark exports from Cameroon over 40 years, showing some of the main policy interventions. No trade data were available for the periods 1991-1994 and 1998-2000. Based on a bark yield of $55 \mathrm{~kg}$ per tree, a $1000 \mathrm{t}$ annual quota represents 18,000 trees debarked/year using the "quarter method". Although the EU ban was in place from 2007 to December 2010, when a 150 t quota was permitted, exports continued, including in 2009 when the Minister of Forestry had declared a "zero quota". Despite concerns about sustainable harvest, a $1092 \mathrm{t}$ quota (worth USD 6.5 million at the current price of USD 6 per $\mathrm{kg}$ ) has been proposed by ANAFOR. 


\section{Results}

\section{1 'Mind the gap'}

On the surface, the "knowing-doing gap" for $P$. africana seems relatively insignificant compared to the chasm between research effort versus effective conservation action on rhino species, for example (Linklater 2003). Nearly 40 years ago, the Government of Cameroon expressed concern about overexploitation of internationally traded medicinal plants (United Republic of Cameroon 1976). In 1991, P. africana harvests in Cameroon were halted by national legislation (Ministry of Agriculture 1991). In 1983, the local prefecture declared a harvest ban on $P$. africana for the Kilum Forest. District-level bans were also declared in 1997 (Ijim Forest), 1998 (Mount Cameroon), 1999 (Southwest region), 20053 and 20064 (Oku Forest). In addition, traditional leaders banned trade due to destructive harvest, with a ban currently in place in Oku area (2014). This action at the national and district levels was followed by international legislation due to concerns about unsustainable wild harvest, with CITES Appendix II listing (2005) and the EU ban on importation (2007) linked to implementation of CITES in the EU5 (Figure 1).

With generous donor support, initiatives to reduce the huge scale of illegal $P$. africana bark exploitation that occurred on Mount Cameroon between 1993 and 1996 (Figure 2a) succeeded. On Mount Cameroon, $P$. africana inventories, management plans and monitoring processes were implemented in which a local institution (MOCAP) is integrally involved. As we discuss later, however, understanding the links between capital accumulation and political power and the actions of "political entrepreneurs" is crucial for the design of lasting solutions to sustainable harvest of valuable natural resources. Ground truthing shows the extent of the gap between rhetoric and reality regarding sustainable harvest of $P$. africana (Table 1).

In addition, the livelihood benefits from $P$. africana have been exaggerated. Claims in the National Management Plan such as "the contribution of Prunus africana to local communities and individual households in the main producing areas

E26/PS/126 Prefectural Order No 17/2005.

E26.03/GSB/19/S.1/288 Sub-Prefectural Decision No 3.

Council Regulation (EC) No 338/97 9 December 1996 on the protection of species of wild fauna and flora by regulating trade therein. of the North West and South West of Cameroon has been significant over the last three decades" (Ingram et al. 2009) and that "for harvesters, Prunus africana is generally very profitable, equivalent to FCFA 3100 (USD 7.03 ) per day, well over a USD 2 a day poverty line" (Ingram 2014) need to be reconsidered.

In reality, $P$. africana bark harvests benefit just $0.0004 \%$ of the local population around Mount Cameroon. No local people benefit directly from bark exploitation from Tchabal Mbabo, as all harvesters are outsiders to the area (Betti 2010). Annual per capita income to harvesters is between USD 356 (our study) and USD 374 (Ingram 2014), an average of USD $0.98-1.02$ per day. In SW, W \& NW Cameroon, households benefit from diverse assets, including migrant remittances, on-farm production and many NTFPs other than $P$. africana. In contrast, a tiny minority of well-connected elites secures most of the benefits. Prices paid to wealthy elite exporters (currently USD 6 per kg, compared to USD 0.33 per kg or less paid to harvesters (Figure 3)) are withheld from bark harvesters and MOCAP.

As $P$. africana is a slow growing species subject to destructive harvest, it could be argued that neither the 1-year ban (1991-1992) nor the EU ban, which barely lasted three years, have been long enough periods to allow wild populations to recover from decades of destructive harvesting.

\subsection{A green economy goes into the red}

The Prunus africana trade in Cameroon could be divided into five phases. Phase 1 (1976-1986) was when Laboratoire Debat (later Plantecam Medicam, then Plantecam) held a monopoly over harvesting and export, using a core team of trained harvesters. Phase 2 (1987-1994) was when commercial harvest was opened to 50 Cameroonian entrepreneurs. Plantecam still controlled the export, but wild $P$. africana populations in NW and W Cameroon, and enrichment plantings implemented by Plantecam near Dschang, were plundered. From 1993, with accessible wild stocks depleted, harvesters from W and NW Cameroon started to exploit $P$. africana on Mount Cameroon, in addition to local Bakweri harvesters who were already operating there. It was during this period that the partial ban on harvest occurred (1991), but this had the opposite effect, with twice annual average amount of bark harvested, bought from local entrepreneurs and exported by Plantecam (Cunningham and 

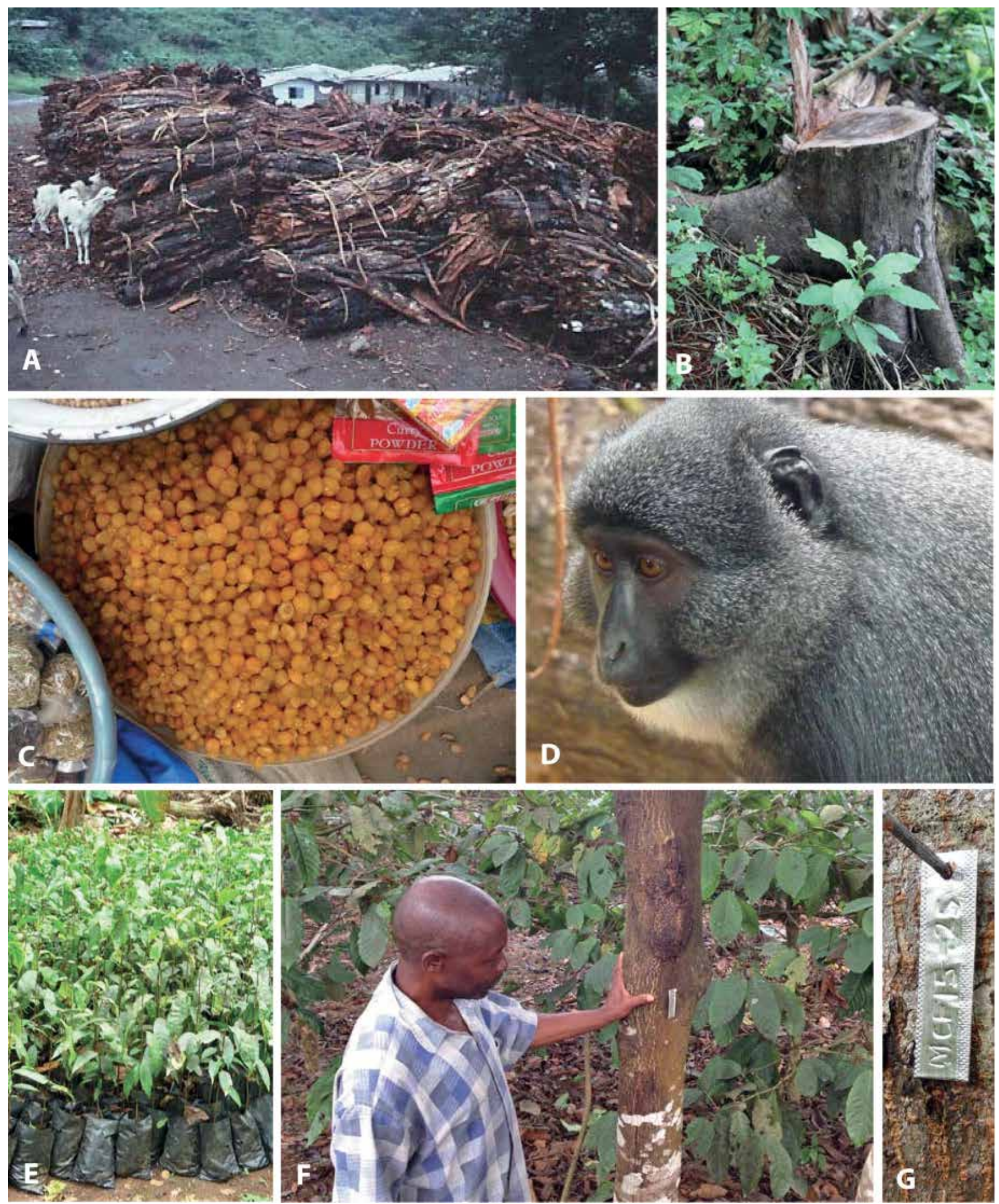

Figure 2. A. Bundles of illegally harvested bark at Mapanja Village, Mount Cameroon in 1993, a period when large-scale destruction of $P$. africana populations took place. B. A P. africana tree felled prior to bark removal, Mount Cameroon (1993). C. Seeds of njangsang (Ricinodendron heudelottii) for sale (2014). Unlike P. africana and Gnetum, these extensively traded seeds are not considered a special forest product. D. Phasing out commercial $P$. africana harvest within conservation areas will benefit endemic species, including Preuss's guenon, which is unique to Cameroon. E. Most on-farm P. africana planting is from wildings or seed. F. A tagged $P$. africana planted in a coffee agroforestry system (Bova 2014). G. One of thousands of cultivated P. africana tagged in farms around Mount Cameroon to facilitate traceable supplies. 
Table 1. Gap analysis between Rhetoric and reality

\begin{tabular}{|c|c|c|}
\hline Theme & Rhetoric & Reality \\
\hline $\begin{array}{l}\text { A 5-year } \\
\text { rotation times } \\
\text { after first bark } \\
\text { harvest }\end{array}$ & $\begin{array}{l}\text { Sustainable harvest of } 50 \% \text { of } \\
\text { trunk bark using the "quarter } \\
\text { method" needs to be based on a } \\
5 \text {-year rotation. This is the basis } \\
\text { of the } 5 \text { blocks of the Prunus } \\
\text { Allocation Unit (PAU) within } \\
\text { Mount Cameroon National } \\
\text { Park (Eben-Ebai 2011). One of } \\
\text { the reasons for the massive } \\
\text { over-estimate of bark yield } \\
\text { from Mount Cameroon (4438 t/ } \\
\text { yr) (Ewusi et al. 1996) was the } \\
\text { assumption of a 4-year rotation. }\end{array}$ & $\begin{array}{l}\text { The five-year rotation is too short. A detailed study by Nkeng } \\
\text { (2009) found that at least a seven-year rotation was necessary. If } \\
\text { wild harvest continues, a } 7-8 \text { year minimum rotation is needed. } \\
\text { The challenge is that longer rotation times mean significantly } \\
\text { lower annual bark harvests. For Mount Cameroon, Eben-Ebai } \\
(2011) \text { has calculated a } 6 \text { years rotation yields } 297.902 \text { tons vs. } \\
377,482 \text { t of fresh bark), } 21 \% \text { less bark than from a } 5 \text {-yr rotation. } \\
\text { In contrast to Euwsi et al.'s (1996) "high estimate" of } 4438 \text { t/yr } \\
\text { from Mount Cameroon, the } 2012 \text { annual bark yield from Block } \\
1 \text { was only } 57 \text { t. With a } 7-y e a r \text { rotation, this would be further } \\
\text { reduced to less than } 40 \text { t per year ( } 100 \text { times less than Ewusi et } \\
\text { al.'s (1996) estimate). }\end{array}$ \\
\hline
\end{tabular}

The "two bark
quarters"
technique is
sustainable.

Only trees with diameter at breast height $(\mathrm{dbh})>30 \mathrm{~cm}$ can be debarked. Trees with $\mathrm{dbh}<$ $50 \mathrm{~cm}$ should be debarked with two strips in opposite sides, each no wider than $1 / 4$ of the tree circumference. Lateral roots with a minimum diameter of 20 $\mathrm{cm}$ on trees $>\mathrm{dbh} 50 \mathrm{~cm}$ can be debarked. Each debarked tree should completely recover before subsequent debarking (Ministry of Agriculture 1986; Ndibi and Kay 1997).
In moist sites, bark regrowth occurs if this technique is used, but in dry sites, bark does not recover. In lower altitude sites, even healthy $P$. africana trees are attacked by wood-bring beetles. Debarking is often followed by reduction in tree crown size due to shoot and branch die-off as a result of water stress due to $50 \%$ bark loss (Cunningham and Mbenkum 1993; Foaham et al. 2009; Nkeng et al. 2009). Water stress is exacerbated by root debarking. In most cases, far more bark is taken than is recommended: "Despite training and the best practice standards and decree, the majority $(61 \%)$ of trees in all the main harvest zones surveyed were debarked unsustainably ... Only $9 \%$ were harvested according to the Two Quarters technique, mainly in privatelyowned plantations and some areas of Mount Cameroon controlled by MOCAP-CIG (Ingram et al. 2009). Even so, even "correct" bark stripping damages the cambium and inhibits bark regeneration.

\begin{tabular}{ll}
\hline Inventories \& & “.. data sources were combined \\
quota setting & [to] create a management \\
& plan which proposes a quota \\
& on the basis of inventories, \\
& verifies harvesting techniques \\
& and contains realistic control \\
& and monitoring regulations" \\
& (Ingram et al. 2009)
\end{tabular}

The National Management Plan included inventories that used different methods, with very different results, even for the same locations. Recommendations that inventories take tree crown health into account (Nkeng 2009) were not followed. The best managed site is the PAU in Mount Cameroon National Park. Previous sampling to establish yields has varied hugely for Mount Cameroon, from $4438 \mathrm{t} / \mathrm{yr}$ to $330 \mathrm{t} / \mathrm{yr}$ to $178 \mathrm{t} / \mathrm{yr}$ and an actual yield in 2012 of just $57 \mathrm{t}$. To avoid inaccurate estimates, GiZ/KfW recently supported a $100 \%$ inventory. This cost 15 million CFA (around USD 30,000) compared to a bark harvest worth USD 17,100 in 2013).

\begin{tabular}{ll}
\hline Sampling & $\begin{array}{l}\text { Adaptive cluster sample method } \\
\text { methods }\end{array}$ \\
& (ACS) is widely considered to \\
be the best method for wild \\
Prunus africana populations (e.g. \\
Ingram et al. 2009; Betti 2011; \\
Betti et al. 2013)
\end{tabular}

Participatory,
decentralized
management

The Prunus allocation units (PAUs) have been participatively defined and developed with input from stakeholders, particularly during Prunus platform meetings, community forests, SNV and the Forest Governance Facility from 2007 to 2009 (Ingram et al. 2009).
Two concerns about the National Management Plan are that: inventories were based on very different sampling methods and the ACS overestimates plant populations (see Morrison et al. 2008). Based on a comparison of 5 different sampling designs, grid-based systematic designs were more efficient and practical than ACS or other methods.

As MINOF does not allocate enough funds for inventories and management plans in PAUs, these are either funded by donors (MCNP), ITTO (e.g. Tchabal Mbabo) or by permit holders who export bark and directly fund ANAFOR staff. Instead of wider participation and devolution of power, centralized control continues through complex permitting processes, with concentration of power through exporter elites. In 2007, just 9 companies received quotas, one of which (Afrimed) continues to dominate the export trade (Figure 4). 


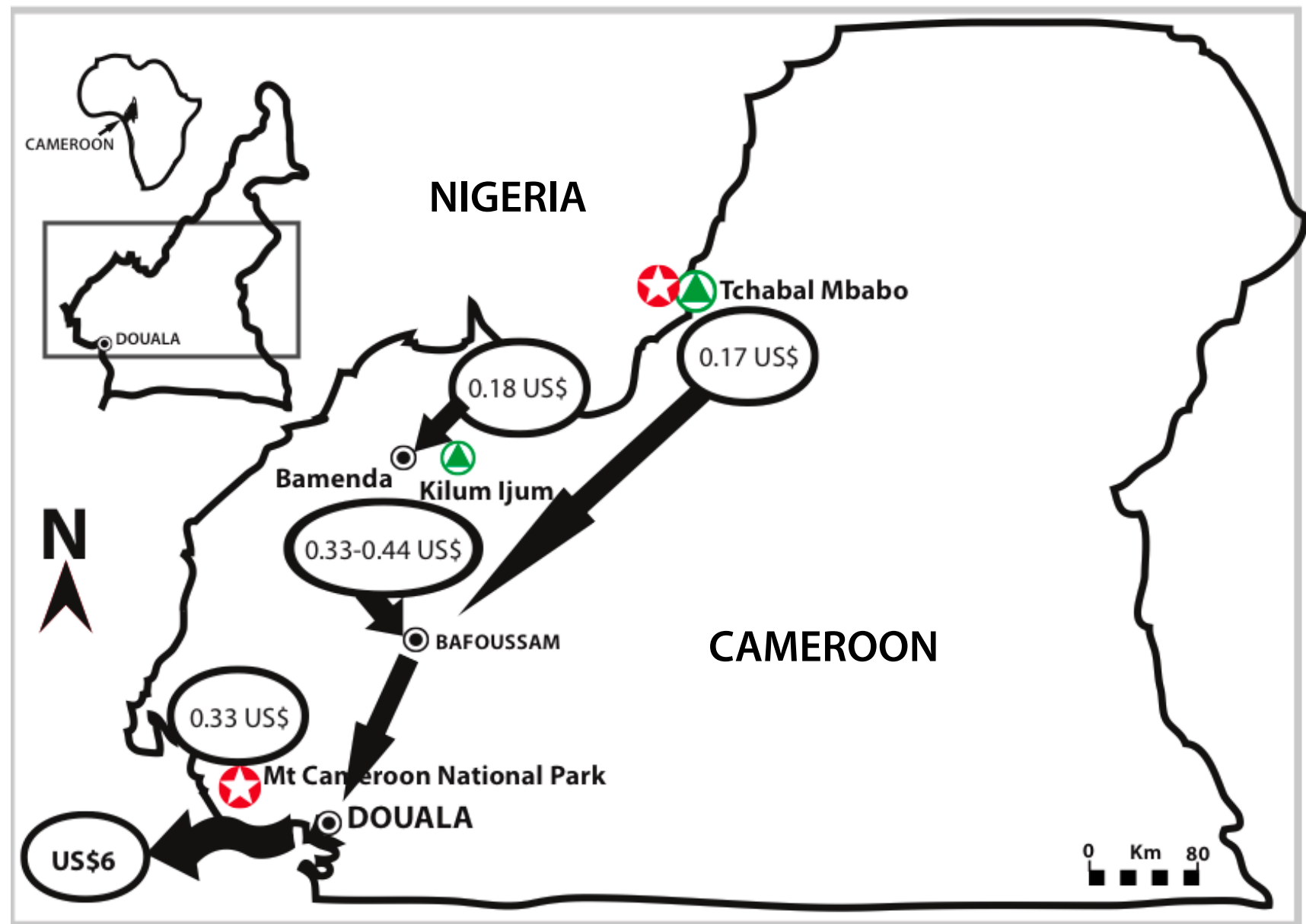

Figure 3. Bark harvesters get paid a fraction of the FOB price per kg of bark paid to elite exporters, even if differences in bark moisture content are taken into account. The lowest prices are paid to harvesters in remote sites. Around Mount Cameroon, where bark harvesters are most organized, there are just 48 active harvesters out of a population of over 100,000 people. None of the harvesters exploiting bark on Tchabal Mbabo are local people. In 2014, all 22 bark harvesters on Tchabal Mbabo were from Bui division, NW Cameroon.

Mbenkum 1993). In 1994, new forestry regulations were introduced in Cameroon. These included classifying $P$. africana as a 'special forestry product'. Controls were put in place on harvest and export through annual, non-renewable, tonnage-based exploitation permits for dried bark harvested within specific allocated zones. ${ }^{6}$ During phase 3 (19952006) Kenya nominated $P$. africana for CITES App II listing in 1994 and this was passed in 1995. This required monitoring of $P$. africana trade and the species was placed on the IUCN Red List (as vulnerable (A1cd)).

Phase 4: 2007-2010: The EU ban in 2007 was necessary to enable $P$. africana stocks to recover, created serious concerns amongst exporter elites, European pharmaceutical companies and high level

\footnotetext{
Fauna and Fisheries Regime (Law No 94/01 of January 20th,
} 1994) and Decree No 94/436 (August, 23rd 1994).
MINOF policymakers. At the time of the EU ban, the lack of a separate supply chain for cultivated $P$. africana bark had resulted in the concentration of power over $P$. africana production through wild harvest (Figure 3), rather than devolving profits and production to the thousands of farmers who cultivate $P$. africana. Based on interviews carried out in NW Cameroon, $80 \%$ of the actors said they knew why the EU trade ban was implemented (Anoncho 2014). Awareness about the reasons for the ban is high (poor P. africana management, no evidence of sustainable exploitation, Cameroon not respecting the attributed quota, and the quality exported was not the best due to bark substitution). Those most affected by EU ban were a powerful Cameroonian elite and the European pharmaceutical companies processing $P$. africana bark. The result was a process of lobbying, advocacy to overturn the ban: a mutiny over the bounty characterized by advocacy dressed up as research (Table 2). 


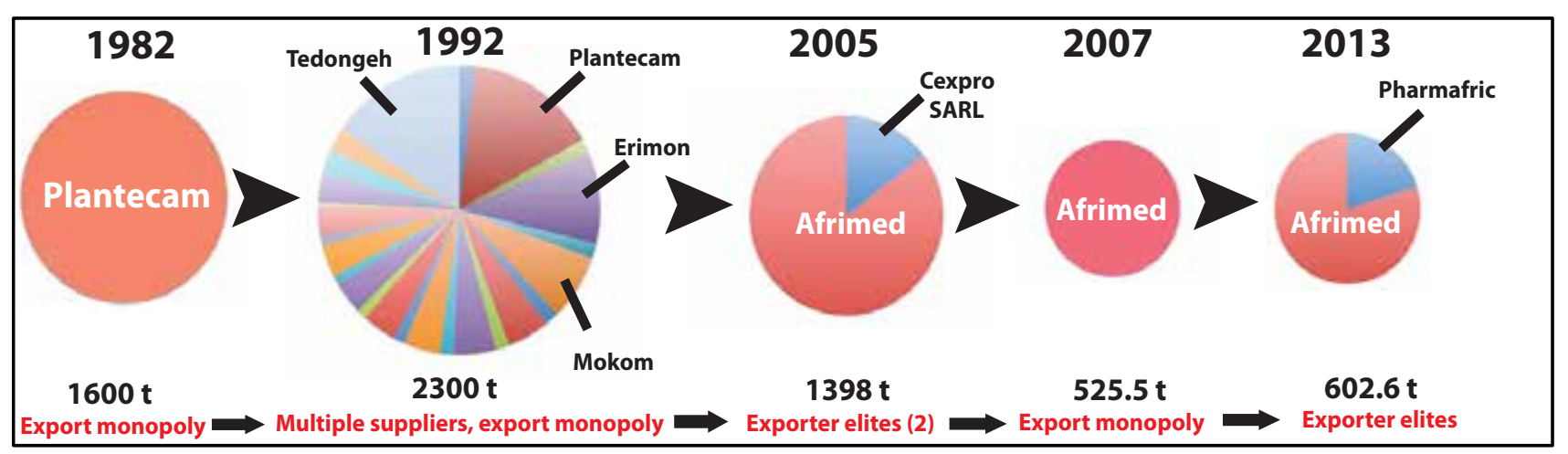

Figure 4. The more things change, the more they stay the same - Despite some diversification, a virtual monopoly over $P$. africana exports by exporter elites continues to be the case.

Phase 5: 2011 and beyond. The question remains on how to go forward following advocacy and lobbying that overturned an effective international policy instrument (the EU ban on trade) that would have allowed $P$. africana stocks to recover? Instead of decentralization through local participation that was supposed to occur under the National Management Plan (Ingram et al. 2009), power and profits from commercial $P$. africana harvest are now in the hands of one or two elite exporters, and are now more centralized than at any time since the period 1976-1986.

\subsection{Plus ça change, plus c'est la même chose}

Following the announcement of the EU ban in 2007, the Government of Cameroon wrote to the EU in May 2007 undertaking to restrict the harvesting of Prunus africana, promising that: "rigorous monitoring and strict control of harvests in situ, will continue". 7 While district and national bans are relatively easy to lift through the influence of political elites, the $2007 \mathrm{EU}$ ban required international influence for it to be lifted. Inventory and monitoring activities also need to be funded if they are to be conducted and sustained. The tool needed by MINOF to convince the EU's Scientific Review Group (SRG) required needed international brand power and credibility. Instead of welcoming the $2007 \mathrm{EU}$ ban as a positive policy change in the face of poor governance, CIFOR supported two MINOF staff, accompanied by a CIFOR researcher

0822/L/MINFOF/SG/DF/SDAFF/SN. Implementation of CITES Convention in the European Union - consultation on the importation of Prunus africana into the European Union. 2 May 2007. to lobby at the CITES Review of Significant Trade Recommendations meeting at Lake Naivasha, Kenya (8-11 September 2008).

In the following month, the Minister of Forestry and Wildlife requested that FAO lead a process to support the development of a management plan that would result in the lifting of the EU ban. FAO commissioned CIFOR to undertake the work. As Ingram (2014) describes, "this forced actors to work together to bricolage new governance arrangements, dictated by international conventions and based on revised formal regulations, customary best practices and projects. The resulting arrangements appear a framework for more sustainable livelihoods in the long term". From an institutional perspective, "bricolage" was not good enough. There were many reservations about the poor quality of the report within CIFOR and it was recommended that the report should not be released. However, as a tool for advocacy and lobbying, the National Management Plan was ideal. Released through the FAO website under the CIFOR/FAO brand, it was submitted to the EU Scientific Review Group (SRG). The EUSRG, unaware of concerns about the quality of the "bricolage" report, accepted it at face value and in 2010, agreed to lift the EU trade ban. Recent interviews with high-level decision-makers in Cameroon and Europe attest to the important role the Ingram et al. (2009) report had in influencing the EU-SRG to lift the trade ban.

The gaps between rhetoric and reality continue to be apparent in advocacy about $P$. africana and livelihoods, sustainable wild harvest and policies on "incentive based conservation" (Tables 1 and 2). In terms of supply chains, geographic distance helps the pharmaceutical companies look "clean 
Table 2. Mutiny over the bounty: Lobbying and advocacy rhetoric as a strategy to overturn the 2007 EU ban.

\begin{tabular}{ll}
\hline Theme & Rhetoric \\
\hline Evidence of & "News of the destructive and large \\
unsustainable & harvests in 2005 and 2006 reached \\
harvest as a & conservation organizations, CITES \\
basis for the & and the EU, stoking fears, at the time \\
$\mathbf{2 0 0 7}$ EU trade & unsubstantiated by evidence, of \\
ban. & unsustainable trade"(Ingram 2014)
\end{tabular}

Reality
For decades, research studies have provided evidence
for destructive and unsustainable commercial harvest
of P. africana, in Cameroon ((Ewusi et al. 1992; Ewusi,
1996; Tchouto 1996; Nkeng 2009), Equatorial Guinea
(Sunderland and Tako 1999) and Madagascar (Walter and
Rakotonirina 1995). Stewart's (2001) matrix population
modeling study concluded that continued harvest of
bark from large trees was totally unsustainable. This and
other evidence was summarized in the CITES Significant
Trade Review (Cunningham 2005) tabled at the CITES
meeting in Lima (2006).

Almost half (46\%) of the actors in the P. africana supply

Impact of the The EU ban was "a tragedy for

2007 EU Trade livelihoods ... abruptly ending exports

ban and leading to a two-year period of uncertainty with little to no income for any actors in the chain" (Ingram 2014)

chain considered the EU trade ban a fair decision, with a further $14 \%$ considering that the EU ban was predictable, given the destructive exploitation of $P$. africana stocks (Anoncho 2014). Only 5\% of respondents said the EU decision was unfair. In NW Cameroon, which is more remote than Mount Cameroon area in the southwest, there is a high level of awareness of the $2007 \mathrm{EU}$ ban, with $54 \%$ of actors aware during 2007 with an additional 38\% becoming an aware of the EU ban in the years after the ban was in place.

\section{Development $\&$ release of the National Management Plan (NMP) in order to have the EU ban lifted.}

National
Management
Plan as a
regional
model

Harvest
within
National Parks
as a policy
outcome of
the National
Management
Plan.

Commercial harvest of $P$. africana bark within Mount Cameroon National Park (MCNP) should be permitted "due to the livelihood and cultural aspects associated with Prunus africana exploitation and seeks to boost community participation in the management and protection of the resources of the park, as well as generate income" (Ingram et al. 2009).

The 2007 EU ban "forced actors to work conventions and based on revised formal regulations, customary best practices and projects. The resulting arrangements appear a framework for term" (Ingram 2014)

The National Management Plan for $P$. africana in Cameroon is a "pragmatic management plan for the sustainable exploitation of Prunus africana in the short and long term. This plan is innovative for Cameroon. It is also relevant for all countries in Africa where Prunus potentially could be exploited".

\section{It was recommended that the "bricolage" report should not} together to 'bricolage' new governance more sustainable livelihoods in the long be released as it included inventories based on different methods and recommended harvest quotas for forests such as Kilum-ljum forest reserve where Steward (2001) had clearly shown harvest was unsustainable. Rather than being a "framework for more sustainable livelihoods in the long term", the report was primarily used as a tool to convince the EU's SRG to lift the ban on P. africana bark imports into the EU.

Although the management plans within Prunus allocation units (PAUs) are the basis of continued wild harvest, it was apparent from CIFOR research (Cerruti et al. 2008) published before the National Management Plan (Ingram et al. 2009) of the massive gap between goals of the 1994 Forestry Policy, which required detailed forest management plans (FMPs) from logging companies and the reality. A total of 14 years after the legislation was in place, the government had still not implementing "effective minimum sustainability safeguards and that, in $2006,68 \%$ of the timber production was still carried out as though no improved management rules were in place". The same applies to $P$. africana today.

As recommended over 20 years ago, commercial harvest should be phased out of Mount Cameroon National Park and forest reserves in favor of cultivation by local farmers (Cunningham and Mbenkum 1993). While onfarm $P$. africana is building up, licensed seed and wildling harvesters should be allowed to collect seed and wildings from MCNP to supply locally run nurseries around the national park. 


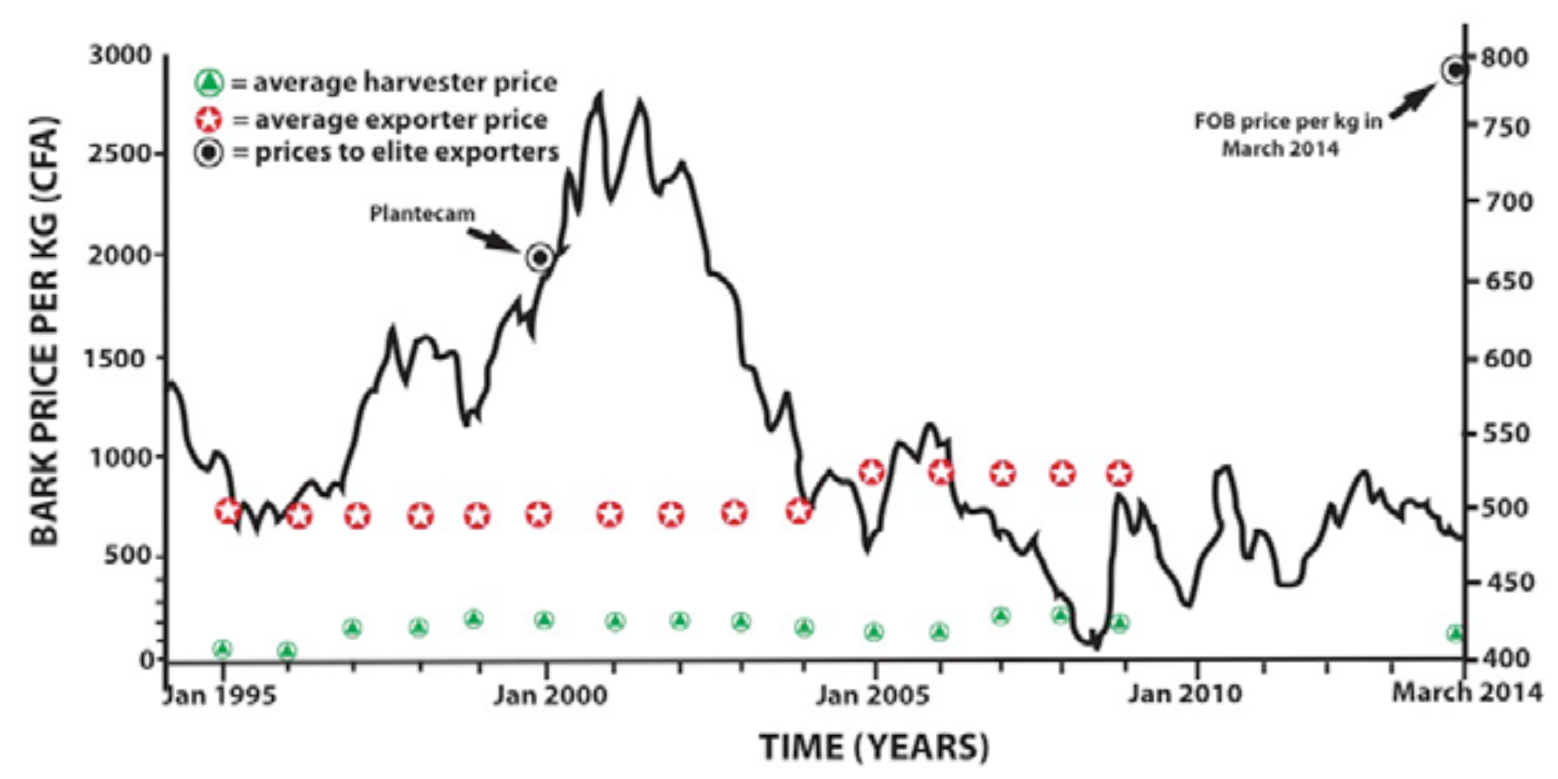

Figure 5. Average prices paid per kg for P. africana bark to harvesters and "exporters" (from Ingram 2014) plotted against the USD/FCFA exchange rate, also indicating prices paid to elite exporters, which despite the decline in the value of the FCFA to the USD, have doubled from USD 3 per kg to USD 6 per kg between 2000 and 2014. Bark harvesters, with limited bargaining power over elite exporters and no information on prices paid by European importers, have to be "price takers". Elite exporters in turn argue that as they pay costs for inventories and management plans (with the exception of Mount Cameroon), they need to pay a low price for bark.

and green”. In fact, Meuer (2008) points out, international pharmaceutical companies get most of the benefits while eluding both the responsibility and the costs of inventories, monitoring and management associated with managed sustainable harvest. Production of advocacy YouTube videos produced with funding from European and North American pharmaceutical companies ${ }^{8}$ (ITTOCITES 2009) and by Bioversity International ${ }^{9}$ (Loo 2011) contributes to the idealistic rhetoric about sustainable wild harvest. ${ }^{10}$ Neither video mentions the need for cultivation as a long-term solution. Loo (2011), for example, cites the 2007 EU ban as the reason why MOCAP harvesters haven't been using their bark-processing machine, thus adding value locally. However, the reason for non-use of the machine is that buyers will not purchase milled bark because it is easily adulterated and obscures the identity of the source species. Advocacy using the National Management Plan (Ingram et al.
2009) and lifting of the 2007 EU ban not only created a windfall for elite exporters, it also placed pressure on MINOF and ANAFOR to request the EU and CITES for larger quotas. While $P$. africana exports were allowed from Cameroon, DRC and Uganda, no quotas were awarded by CITES to Burundi, Madagascar, Kenya or Equatorial Guinea (CITES 2012). This created a global shortage of $P$. africana bark, pushing up bark prices and increasing Cameroon's global share of the $P$. africana market, from an average of $38 \%$ between 1995 and 2004 to $72.6 \%$ (658.6 t) in 2012. In 2000, for example, Plantecam sold exported $P$. africana bark for CFA 2000 per $\mathrm{kg}$ (USD 3 per $\mathrm{kg}^{11}$ ). Lifting the EU ban was conditional on a reduced quota of $150 \mathrm{t}$ for 2010, $280 \mathrm{t}$ in 2011 and $658 \mathrm{t}$ in 2012. In February 2014, National Forestry Development Agency (ANAFOR) requested that the SRG increase the annual quota to $1092 \mathrm{t}$. This would be worth USD 6.5 million at the current price of USD 6 per kg.

11 At the 2000 exchange rate of 650 FCFA $=1$ USD.

\footnotetext{
http://www.youtube.com/watch?v=VyGUMPGYQ6o

9 http://www.youtube.com/watch?v=LZLMc8eLgG8

10 But see the following for an alternative view: http://www. youtube.com/watch?v=WmoSPOEFvMY
} 
Table 3. Green production and red herrings: A reality check on $P$. africana cultivation.

\begin{tabular}{ll}
\hline Theme & Rhetoric \\
\hline Trade from cultivated & $\begin{array}{l}\text { Significant quantities } \\
\text { of bark in the export } \\
\text { trade are from } \\
\text { cultivation }\end{array}$ \\
&
\end{tabular}

Reality

The majority of exported bark is from wild harvest. Although many

farmers have planted P. africana since 1977 (Cunningham and Mbenkum 1993) and cultivation is a viable economic proposition (Cunningham et al. 2002), relatively few farmers are harvesting bark for sale. Some are so discouraged by poor prices they are paid for bark that they are cutting down their trees for use as timber (personal communication from P. Tchouto, 2014). In west Cameroon, although more than $94 \%$ of farmers plant, at least $90 \%$ of $P$. africana bark is still exploited from the forest (ICRAF/ IRAD/University of Dschang 2008). Approximately $70 \%$ had never been harvested (Ingram et al. 2014). The EU ban stimulated commercial farmers and pharmaceutical companies to consider partnerships for cultivation (Ingram 2014). Separate supply chains for cultivated bark, and farmers groups who cooperate in selling container loads of traceable high-quality bark for fair prices, are required.

\begin{tabular}{ll}
\hline $\begin{array}{l}\text { Use of the } \\
\text { "regeneration tax" }\end{array}$ & $\begin{array}{l}\text { The regeneration } \\
\text { tax funds P. africana } \\
\text { cultivation }\end{array}$ \\
\hline
\end{tabular}

Most informants are unclear about what happens to this tax. It is collected specifically to fund reforestation efforts for $P$. africana, yet MINFOF admit that they do little or no work of this kind.

Recognition of extensive $P$. africana cultivation by local farmers

\section{"These facts} demonstrate the previously unrecognized large-scale of domestication" (Ingram 2014)

Conservation of $P$. africana genetic diversity
The extent of $P$. africana cultivation by local farmers was recognized over 20 years ago (Cunningham and Mbenkum 1993). A follow-up study showed that $P$. africana cultivation was an economically viable option (Cunningham et al. 2003). However the production potential of planted stands is still poorly documented.

\section{Cutlivated stocks of} P. africana are"an important genetic source" (Ingram et al. 2009; Ingram 2014)
For years, Plantecam supplied seed to farmers. However, seed collection has been primarily opportunistic and not based on a systematic attempt at genetic selection, thus the genetic value of much cultivated stock is unknown. A comparative analysis of genetic diversity among cultivated and natural stands in the northwest region indicated no significant difference, indicating that the current domestication strategy helps conserve the genetic diversity found in natural populations (Avana et al. 2008)

\begin{tabular}{ll}
\hline $\begin{array}{l}\text { Cultivated } P \text {. africana } \\
\text { trees should be }\end{array}$ & $\begin{array}{l}\text { Cultivated trees are } \\
\text { the first generation } \\
\text { considered wild for } \\
\text { permitting purposes. }\end{array}$ \\
& from wild collected \\
& seed or wildings, \\
& so should be \\
& considered wild and \\
& must come under \\
& MINFOF wild harvest \\
& permit system
\end{tabular}

\section{Debarking of} cultivated trees \& the "two quarters method"
This may be a strategy to get additional taxes and retain control, rather than allow decentralized production and trade through separate, traceable supply chains. Separate supply chains have been implemented for farmed CITES listed species as diverse as orchids and crocodiles and are possible for Aquilaria resin (agarwood) as well (Espinoza et al. 2014).
Farmers are so used to hearing about the "two quarters methods" that they want to apply this to trees on farm.

It is likely to be more economically viable to fell cultivated $P$. africana trees, to harvest $100 \%$ of bark, sell the timber and branchwood (for timber and fuel). 


\subsection{Back to the future: cultivating a green economy}

There is general consensus between researchers, advocacy groups and farmers that cultivation is necessary to sustain future trade. Over 20 years ago, detailed recommendations were made for a shift from wild $P$. africana bark harvest to supplies from cultivated stocks (Cunningham and Mbenkum 1993). Although many of those recommendations were followed by ICRAF (Gyau et al. 2013), the Limbe Botanic Garden (Sunderland et al. 2002) and many other local organizations, gaps in understanding about cultivation remain (Table 3 ). The biggest gap of all is the lack of a separate supply chain for cultivated P. africana bark. Re-instating an EU ban on wild harvested bark exports with a traceable supply chain in place would produce a very different outcome. Local farmers are overwhelmingly in favor of selling their bark at a fair price and avoiding the taxes currently imposed on wild harvested bark. These taxes represent $57 \%$ of the farm-gate price for cultivated bark (Figure 6). With tagging of cultivated trees, the process of developing a separate supply chain for cultivated $P$. africana bark is underway.

Yet at the local livelihood level, far more people would benefit, with considerably less effort, from policy changes and market access that encouraged cultivation. In 2008, before CIFOR's involvement in developing the National Management Plan started, it was recommended that CIFOR's $P$. africana research focus on cultivation, not on wild harvest, on the basis of recommendations over the past 20 years that cultivation was the most practical way of sustaining supplies (Cunningham and Mbenkum 1993; Cunningham et al. 2002). This advice was ignored; the National Management Plan was produced, and the EU ban was lifted after 3 years. It is in the best interest of pharmaceutical companies whose customers are increasingly aware of Fair Trade and "green economies" to help develop traceable supply chains for cultivated $P$. africana bark. This is sorely needed. From 2003 to 2011 , the source of more than half $(57 \%)$ of the $P$. africana bark exported from 2003 to 2011 was unknown, as no official distinction was made between legal and illegally harvested bark (Ingram 2014). The current GiZ/PSMNR-SW-funded inventory of $P$. africana on farms is therefore very timely as is the availability of new technologies that can facilitate tracking, such as barcoding and smartphones used to read barcodes on sealed bags of cultivated bark.

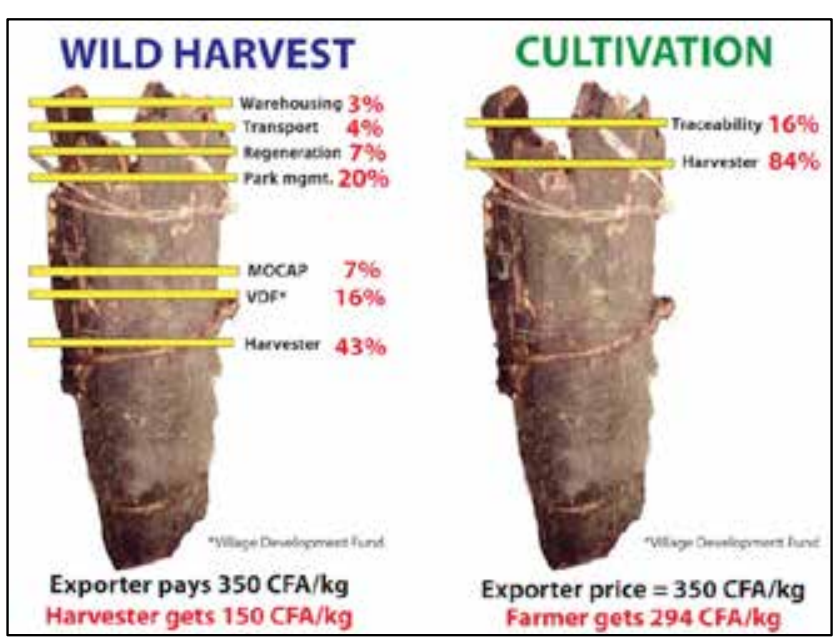

Figure 6. Bark production from cultivation will bring better profits with less effort as long as government officials allow cultivated $P$. africana to be recognized as cultivated and not "wild because they are first generation produced from wild collected wildings or seed".

\section{Discussion}

Worldwide, there are many instances where research or monitoring have failed to influence policy decisions or positive actions on natural resource use or conservation. Linklater's (2003) global synthesis of rhino research, for example, showed that all rhino species were declining while rhino research outputs had increased. P. africana is a similar case of the "knowing but not doing" gap. Habel et al. (2013), identified not one gap, but three gaps between conservation science and conservation action: (i) the "knowing-doing gap"; (ii) a thematic gap between the topics addressed by conservation science and the problems faced in conservation; and (iii) a disciplinary gap, with Habel et al. (2013) calling for interdisciplinary research at multiple scales in the field of biodiversity and conservation science. In the P. africana case, bridging the "'knowing-doing gap" requires transdisciplinary research (Max-Neef 2005) that goes way beyond conservation science into political ecology and environmental economics.

In 1994, when $P$. africana was listed in CITES Appendix II at CoP9, many factors related to "nondetriment findings" (NDF) were known. These were: (i) the scale of the commercial bark trade on stocks depleted by habitat loss and destructive harvest; (ii) that $P$. africana populations across Africa and Madagascar were chemotypically (Martinelli et al. 1986) and genetically distinct (Barker et al. 1992); (iii) 
that bark regeneration in drier sites was limited and crown die-back occurred; (iv) that poor governance was a key factor behind over-harvest, including within high conservation priority areas and (v) that small-scale farmers in Cameroon were producing many $P$. africana in agroforestry systems and it was important to phase out harvesting of wild stocks and shift to bark exports from cultivated stocks (Cunningham and Mbenkum 1993; Tchoundjeu et al. 2002).

What wasn't fully appreciated then, but is known now, are six additional factors that need to be considered in NDF. First, climate change influences on $P$. africana populations (Mbatude et al. 2012; Vinceti et al. 2013). The range of the species has been affected by past climate change and the modeled distribution of $P$. africana indicates that the species is likely to be negatively affected in future, with an expected decrease in distribution by 2050 (Vinceti et al. 2013). Second, although pioneering work had been undertaken on chemotypic (Martinelli et al. 1986) and genetic variation in P. africana (Barker et al. 1994), the extent of variation across different sites, and the need for conserving this variation of $P$. africana populations remains. This genetic and chemotypic variation reflects ancient dispersal routes and evolution of $P$. africana in separate and vulnerable montane forest "islands" in Africa and Madagascar (Kadu et al. 2011, 2012a, b; Vinceti et al. 2013). Third, current destructive harvesting practices affect the reproductive future and genetic diversity of exploited populations (Farwig et al. 2008). Fourth, matrix population modeling based on fieldwork in Cameroon showed that $P$. africana population growth rates are most sensitive to death or low survival rates of the large trees producing the most seed and that exploitation of large P. africana trees is unsustainable and leads to population decline (Stewart 2001). Fifth, that due to the cyanogenic glycosides it contains, $P$. africana is a fundamentally important species in the diet of rare primates such as red colobus (Chapman and Chapman 1999; Chapman et al. 2003) and black-and-white colobus monkeys (Fashing 2004). Six, two types of additional "collateral damage" accompanying $P$. africana harvest are not being taken into account:

- bushmeat hunting;

- felling of "ladder trees" and the lianas that bind them together.

All $P$. africana harvesters are men, often with hunting experience. In Mount Cameroon National Park, and possibly elsewhere, harvesters are encouraged to climb $P$. africana trees using makeshift ladders using local materials (small trees bound with lianas).
A $1000 \mathrm{t}$ quota represents an estimated 18,000 P. africana trees being debarked, as many "ladder trees" felled and at least two lianas per ladder (36,000 lianas). This may have no effect on species populations or the forest, but it does need attention. Finally, despite the firm recommendation that no P. africana harvesting should take place within the areas set aside for Afromontane forest conservation (Cunningham and Mbenkum 1993), commercial $P$. africana bark harvest would be allowed to continue within Mount Cameroon National Park (Eben-Ebai 2011) and Nkom-Wum Forest Reserve, Mount Manenguba. MINFOF would continue to permit commercial bark harvest (Bellekwang 2006).

The decision made at the 42nd Meeting of the European Union Scientific Review Group (SRG) on 7 December 2007, where the EU decided to ban importation of $P$. africana bark, stimulated an unprecedented level of lobbying and rhetoric in order to overturn the EU decision. Decisions based on advocacy rather than on research and action to develop separate supply chains for $P$. africana farmers has delayed a lasting solution for a sustainable $P$. africana trade. Globally, virtually all major sources of tree bark in commercial trade have made the transition from cultivation in agroforestry systems or plantations (i.e. wattle, cinnamon, cassia, quinine). Over twenty years ago, recommendations were made that $P$. africana follow the same path and that wild harvest within conservation areas should cease (Cunningham and Mbenkum 1993), yet most research has focused on wild harvest. In many ways, the $P$. africana case is replete with ironies, contradictions and unintended consequences.

Why is there such a disconnect between policymakers and lobby groups, and what is really happening in the forest? In Cameroon, there are many parallels between policy and practice of trade in timber and in P. africana bark. As Cerruti et al. (2008) points out for timber, Cameroon "needs more than approved management plans". So does $P$. africana. In Madagascar, powerful elites have subverted regulations on $P$. africana harvest and trade (Neimark 2010). Médard's (1992) characterization of the 'political entrepreneur' who merges his roles as politician, government official, and businessman is particularly useful in the $P$. africana case. The export of forest resources (such as timber and medicinal barks from Prunus africana and Pausinystalia yohimbe) is an important source of revenue. So is development aid. Since Cameroon's independence, for example, Germany has provided $€ 906.3$ million to Cameroon. 
Following an agreement signed in December 2013, Germany will make an additional contribution of $€$ 94.5 million to Cameroon (2014-2016), specifically aimed at decentralized governance, sustainable use and rural development. The most influential stakeholders in the P. africana supply chain are government officials within MINFOF (including ANAFOR) and elite exporters. As Ingram (2014) eloquently describes:

Corruption feeds off and thwarts the statutory permitting procedures controlling access to the resource, monitoring and sanctioning. The high level of regulation of this high value trade and the small number of harvest areas, channels and actors through which the trade flows - provides a lucrative opportunity for corrupt officials. This then further exacerbates regulatory and customary failures. Corruption aggravates the challenges actors have to operate legally, promoting rather informality and illegality as a (slightly) easier and apparently profitable way of doing business. Corruption thus became an insidious, predictable but incalculable governance arrangement and may continue to do so under the revised Management Plan, as unprecedented power is channelled via government officials controlling inventories rather than participative inventories.

\section{Lifting the ban on $P$. africana exports from} Cameroon, while zero quotas were in place for competitor countries (such as Burundi, DRC and Kenya) created an ideal business opportunity for elite exporters. In theory, as with timber concessions in Cameroon, allocation of PAUs was meant to occur after an advertised, open, competitive bidding process. In practice, even where local organizations are involved, they have to link up with exporter elites who through MINFOF, are granted exploitation permits after the exporters have paid ANAFOR staff to conduct inventories on their behalf. In 2012, although Pharmafric was granted a quota in the remote, "resource rich frontier" of the Adamoua plateau (which has five PAUs) we were told that harvested quantities within their allocated PAU were far lower than they expected. Despite Afrimed having a history of paying low prices and of unsustainable $P$. africana bark harvests (Meuer 2008), it continues to be the dominant exporter. Afrimed is part of Afrigroup, a very wellconnected business consisting of four companies under the umbrella of a large Cameroonian bank. The irony of funds from the German development bank (KfW) subsidizing a profit making $P$. africana exporter linked to a Cameroonian bank seems to have been lost in earlier policy dialogue. Owned by a Cameroonian entrepreneur, the Afrigroup wields significant influence well beyond forest products, through Afribank (created in 1998; annual turnover USD 1.8 million), Afrimed (created in 1995) with facilities in Bafoussam and Douala where the bark is stored and macerated before export), Afrilec SARL (an electronic goods importer) and Afriexchange (a foreign exchange business with capital of USD 201 million) (Anon 2005). Although banking, importing electronic goods and dealing in foreign exchange can be profitable businesses, there is no doubt that at exporting $P$. africana on a large scale is profitable too. The current price paid by a German company for a 20-foot container load of P. africana bark ((on basis FOB African origin or CIF European destination) is USD 6 ( $€$ 4.32) per $\mathrm{kg}$ on delivery in Hamburg with CITES documents (personal communication from J Brinckmann, 2014)). Cameroon's labor costs of chopping a ton of bark are a small proportion of this gross revenue. The cost of shipping a 20 -foot container to Hamburg is around USD 2000, giving a significant profit margin. Prices paid to bark harvesters have not reflected international exchange rates, but for elite exporters, bark has become a hedge against the declining value of the FCFA (Figure 5). For example, the 2012 bark quota $(658.675 \mathrm{t})$ would be worth over USD 3.9 million. It is no wonder, therefore, that a request was made through ANAFOR to the EU SRG in February 2014 to increase the 2014 quota to $1092 \mathrm{t}$, as this would be worth USD 6.5 million.

We now know more than enough to bridge the "knowing but not doing gap". Many of the problems that Ingram et al. (2009) sought to resolve - unsustainable harvest, quotas greater than wild sustainable stocks and low income to wild bark harvesters - persist. So do the contradictions between decentralization implicit in Cameroon's 1994 forestry law and highly centralized power over rights to harvest special forest products, including P. africana. But the ripple effects of assuming that Cameroon's wild harvest model (Ingram et al. 2009) can be applied elsewhere are serious. These include $P$. africana bark assessments that were carried out in and around national parks in Burundi and in DRC (Betti 2012; ITTO-CITES 2012). These conservation areas occur in Africa's most biodiverse ecoregion, with an extremely high number of threatened and endemic species. More than ever before, pragmatic policies need to be based on thorough research and on- theground reality checks. 


\section{$5 \quad$ References}

Abensperg-Traun M. 2009. CITES, sustainable use of wild species and incentive-driven conservation in developing countries, with an emphasis on southern Africa. Biological Conservation 142:948-63.

Amougou A, Betti J-L, Ewusi BN, Mbarga N, Akagou Zedong HC, Fonkoua C, Mala AW and Nkouna AC. 2011. Preliminary report on sustainable harvesting of Prunus africana (Roasaceae) in the Mount Cameroon National Park. Report prepared for the National Forestry Development Agency (ANAFOR), the Cameroon CITES Scientific Authority for flora, for the project, Non-detriment findings for Prunus africana (Hook. F) Kalkman in Cameroon. http://www.itto.int/files/user/cites/ cameroon/NDF_Prunus_ANAFOR_Mount_ Cameroon1.pdf

Anon. 2005. Investment forum: Projects \& financing. 4-8 April 2005, Washington, DC 2005. The African Investment Corporation and The US Embassy in Cameroon. Accessed 4 July 2014. http://www.africaninvestcorp.com/ InteriorPages_FINAL.pdf

Anoncho FV. 2014. NTFP governance: The case of Prunus africana management in the northwest province of Cameroon. [Masters thesis] Cameroon: University of Dschang.

Avana ML. 2006. Domestication de Prunus africana: Etude de la germination et du bouturage. $[\mathrm{PhD}$ thèse] Cameroon: Université de Yaoudé 1.

Barker NP, Cunningham AB, Morrow C and Harley EH. 1994. A preliminary investigation into the use of RAPD to assess the genetic diversity of a threatened tree species: Prunus africana. Strelitzia 1:221-30 In Huntley BJ, ed. Botanical Diversity in Southern Africa. National Botanical Institute, Pretoria.

Belinga SJ and Mbarga NL. 2014. Gestion durable et commerce de Prunus africana au Cameroun: Rapport sur les ACNP de 2011,2012 et 2013. Session du Groupe d'Examen Scientifique de la Commission Européenne: Bruxelles, le 27 février 2014

Bellewang EN. 2006. Socio-economic impact of Prunus africana management in the Mount Cameroon region. A case study of the Bokwoango community. [Masters thesis]. Stockholm, Sweden: Kungliga Tekniska Hogskolan.

Betti J-L. 2011. Premiers resultats sur le potentiel sur pied de Prunus africana (Rosaceae) dans la province du Nord-Kivu en Republique Democratique du
Congo. Rapport préparé par l'Institut Congolais pour la Conservation de la Nature (ICCN), Autorité Scientifique de la CITES en République Démocratique du Congo, dans le cadre du Projet "Avis de commerce non préjudiciable sur Prunus africana en RDC".

Betti J-L., Feruzi M, Rushemeza J, Rurantije A, Nzigiyimpa L, Ndabahagamye F, Ahishakiye J, Manariyo D, Buvyiruke E, Ndayishimiye JC, et al. 2013. Exploitable stock of Prunus africana stems in the Teza Forest, Kibira National Park, Burundi. International Journal of Agriculture Innovations and Research 2(3):317-26.

Buchwaldt C. 1996.Untersuchungen zum Vorkommen und zur intensitât der Rindennutzung von Prunus Africana am Mont Cameroon in Kamerun. Fachbereich Biologie der Universität hamburg. Hamburg, Germany.

Cerutti PO, Nasi R and Tacconi L. 2008. Sustainable forest management in Cameroon needs more than approved forest management plans. Ecology and Society 13(2):36. [online] URL: http://www. ecologyandsociety.org/vol13/iss2/art36/

Chapman CA and Chapman LJ. 1999. Implications of Small-scale variation in ecological conditions for the diet and density of red colobus monkeys. Primates 40(1):215-31.

Chapman CA, Chapman LJ, Rode KD, Hauckand EM and McDowell LR. 2003. Variation in the nutritional value of primate foods: Among trees, time periods, and areas. International Journal of Primatology 24: 317-33.

Cunningham AB. 2005. CITES Significant Trade Review of Prunus africana. In Review of Significant Trade in Specimens of AppendixII Species. Sixteenth Meeting of the Plants Committee, Lima (Peru), 3-8 July 2006. PC16 Doc.10.2. Available: www.cites.org/eng/com/ pc/16/E-PC16-10-02.pdf. 3-30.

Cunningham AB, Ayuk E, Franzel S, Duguma B and Asanga C. 2002. An economic evaluation of medicinal tree cultivation: Prunus africana in Cameroon. People and Plants Working Paper No. 10. UNESCO, Paris, France.

Cunningham AB and Cunningham M. 2000. Profits, Prunus and the prostate: International trade in tropical bark. In Zerner C, ed. People, Plants and Justice: The Politics of Nature Conservation. New York: Columbia University Press. 309-44

Cunningham $\mathrm{M}$, Cunningham $\mathrm{AB}$ and Schippmann U. 1997. Trade in Prunus africana and the implementation of CITES. German Federal Agency for Nature Conservation, Bonn, Germany. 
Cunningham A and Mbenkum FT. 1993 Sustainability of harvesting Prunus africana bark in Cameroon - a medicinal plant in international trade. People and Plants Working Paper No. 2.

Dawson IK and Powell W. 1999. Genetic variation in the Afromontane tree Prunus africana, an endangered medicinal species. Molecular Ecology 8:151-56.

[DGEF]. Direction Générale des Eaux et Forêts. 2003. Plan d'action national pour la gestion durable $d u$ Prunus africana. Ministèere de l'Environment, des Eaux et Forêts. Direction Générale des Eaux et Forêts. Comité National Prunus africana.

Duone E. 2008. The exploitation and conservation of Prunus africana in the Mount Cameroon region of Cameroon. [Masters thesis]. Sweden: Sodertorns University College.

Eben-Ebai S. 2011. Prunus africana management plan for the Mount Cameroon National Park and its support zone. Regional Delegation of Forestry and Wildlife and the Programme for the Sustainable Management of Natural Resources for the South West (PSMNR-SW), Buea, Cameroon. 36 pp.

Ekane NB. 2005. Socio-economic impact of Prunus africana management in the Mount Cameroon region of Cameroon: A case study of the Bokwoango community. [Masters thesis]. Sweden: Royal Institute of Technology.

Espinoza EO, Lancaster CA, Kreitals NM, Hata M, Cody RB and Blanchette RA. 2014. Distinguishing wild from cultivated agarwood (Aquilaria spp.) using direct analysis in real time and time-of-flight mass spectrometry. Rapid Communications in Mass Spectrometry 28(3):281-89.

Farwig N, Carsten B and Bohning-Gaese K. 2008. Human disturbance reduces genetic diversity of an endangered tropical tree, Prunus africana (Rosaceae). Conservation Genetics 9:317-26.

Fashing PJ. 2004. Mortality trends in the African cherry (Prunus africana) and the implications for colobus monkeys (Colobus guereza) in Kakamega Forest, Kenya. Biological Conservation 120:449-59.

Fotso DS. 2006. Institutional perspective on forest management in the Kilum-Ijim Forest Area, Cameroon. [Masters thesis]. Norway: University of Oslo.

Gyau A, Chiatoh M, Franzel S, Asaah E and Donovan J. 2013. Determinants of farmers' tree planting behaviour in the north west region of Cameroon: The case of Prunus africana. International Forestry Review 14:265-74.
Habel JC, Gossner MM, Meyer ST, Eggermont H, Lens L, Dengler J and Weisser WW. 2013. Mind the gaps when using science to address conservation concerns. Biodiversity Conservation 22:2413-27.

Hall JB, O'Brien EM and Sinclair LF. 2000. Prunus africana: A Monograph. School of Agricultural and Forest Sciences. Publication No. 18. University of Wales, Bangor.

Ingram V. 2014. Win-wins in NTFP value chains: How governance impacts the sustainability of livelihoods based on Congo Basin forest products. [PhD thesis]. The Netherlands: University of Amsterdam.

Ingram V, Awono A, Schure J and Ndam N. 2009. National Management for Prunus a fricana, Cameroon. GCP/RAF/408/EC. CIFOR, FAO. $158 \mathrm{p}$.

ITTO-CITES. 2009. Custodians of the forest. http:// www. youtube.com/watch?v=4J9JVBvMAr8

Kadu CAC, Konrad H, Schueler S, Muluvi GM, Eyog-Matig O, Muchugi A, Williams VL, Ramamonjisoa L, Kapinga C, Foahom B, et al. 2012. Divergent pattern of nuclear genetic diversity across the range of the Afromontane Prunus africana mirrors variable climate of African highlands. Annals of Botany 111(1):47-60.

Kadu CAC, Schueler S, Konrad H, Muluvi GM, Eyog-Matig O, Muchugi A, Williams VL, Ramamonjisoa L, Kapinga C, Foahom B, et al. 2011. Phylogeography of the Afromontane Prunus africana reveals a former migration corridor between East and West African Highlands. Molecular Ecology 20:165-78.

Kadu CAC, Parich A, Schueler S, Konrad H, Muluvi GM, Eyog-Matig O, Muchugi A, Williams VL, Ramamonjisoa L, Kapinga C, et al. 2012. Bioactive constituents in Prunus africana: Geographical variation throughout Africa and associations with environmental and genetic parameters. Phytochemistry 83:70-8.

Knight A, Cowling RM, Rouget M, Balmford A, Lombard AT and Campbell BM. 2008. Knowing but not doing: Selecting priority conservation areas and the researchimplementation gap. Conservation Biology 22:610-17.

Laird, SA, Ingram V, Awono A, Ndoye O, Sunderland T, Lisinge Fotabong E and Nkuinkeu R. 2010. Integrating customary and statutory systems: The struggle to develop a legal and policy framework for NTFPs in Cameroon. In Laird SA, McLain R and Wynberg R, eds. Wild Product Governance: Finding Policies that Work for Non-timber Forest Products. Earthscan, London, 53-70. 
Linklater WL. 2003. Science and management in a conservation crisis: A case study with rhinoceros. Conservation Biology 17(4):968-75.

Loo J. 2011. On the trail of the African cherry tree. http://www.youtube.com/ watch?v=LZLMc8eLgG8

Macleod H.L., 1986. The conservation of Oku mountain forest, Cameroon. International council for bird presentation study report, 15: 1-90.

Martelli EM, Seraglia R. and Pifferi G. 1986. Characterization of Pygeum africanum bark extracts by HRGC with computer assistance. Journal of High Resolution Chromatography \& Chromatography Communications 9:106-10.

Max-Neef M. 2005. Foundations of transdisciplinarity. Ecological Economics 53:5-16.

Mbatudde M, Mwanjololo M, Kakudidi EK and Dalitz H. 2011. Modelling the potential distribution of endangered Prunus africana (Hook. F.) Kalkm. in East Africa. African Journal of Ecology. doi:10.1111/j.13652028.2012.01327.x

Meuer K. 2008. Extraction of Prunus africana in the proposed Mount Cameroon National Park: Perspectives of community-based sustainable management. University of Greifswald, Germany.

Ministry of Agriculture. 1992. Portant levee de la suspension de l'exploitation du Pygeum. Yaounde, 14 February, 1992. Arrete no. 48/A/ MINAGRI/DF/SEF.

Ministry of Agriculture. 1991. Portant suspension de l'exploitation du Pygeum etannulation des permis speciaux comprenant le Pygeum. Yaoundé, 28February, 1991. Arrete no. 11/A/ MINAGRI/DF/SEF.

Ministry of Agriculture. 1986. Cahier des charges, permis d' exploitation des essences forestieres speciales.Ministry of Agriculture No 405/ MINAGRI/DEFC. Yaoundé, Cameroon.

[MOCAP] Mount Cameroon Prunus Management Common Initiative Group. 2006. Acquisition of Prunus africana bark processing equipment by MOCAP GIC to promote on the sustainable management of the Prunus plant amongst the communities in the Mount Cameroon region. MOCAP, Buea, Cameroon. 29 p.

Morrison LW, Smith, DR, Young CC and Nichols DW. 2008. Evaluating sampling designs by computer simulation: A case study with the Missouri bladderpod. Population Ecology 50(4):417-25.

Ndam N. 1998. Tree regeneration. Vegetation dynamics and maintenance of biodiversity on Mount Cameroon: The relative impact of natural and human disturbance. [Ph.D. thesis]. University of Wales.

Ndibi BP and Kay EJ. 1997. The regulatory framework of medicinal plants in Cameroon; the case of Prunus africana on Mount Cameroon. Biodiversity and Conservation 6:1409-12.

Neimark B. 2010. Subverting regulatory protection of 'natural commodities': The Prunus africana in Madagascar. Development and Change 41(5):929-54.

Nkeng, P.F. 2009. Sustainable management of Prunus africana (Hook.f.) Kalk. in Cameroon: an assessment of exploitation methods in Southwest, North-west and Adamaoua vicinities. Faculty of Agronomy and Agricultural sciences, University of Dschang.

Nkeng, P. F., V. Ingram, A. Awono and M.-L. A. Tientcheu (2009), Assessment of Prunus africana bark exploitation methods and sustainable exploitation in the South west, North west and Adamaoua regions of Cameroon. Project GCP/ RAF/408/EC. Mobilisation et Renforcement des Capacités des Petites et Moyennes Entreprises impliquées dans les Filières des Produits Forestiers Non Ligneux en Afrique Centrale. CIFOR. Yaoundé: FAO-CIFOR-SNV-World Agroforestry Center-COMIFAC: 57.

Ntsama G-L. 2008. Exploitation Des PFNL (Cas du Prunus africana) et réduction de la pauvreté en milieu rural. Mémoire de [Masters thesis] Université de Yaoundé II, Yaoundé, Cameroun.

Ribot JC. 1998. Theorizing access: Forest profits along Senegal's charcoal commodity chain. Development and Change 29(2):307-41.

Ribot JC and Peluso NL. 2003. A theory of access. Rural Sociology 68(2):153-81.

Singer B. 2008. Cameroonian Forest-Related Policies. A Multisectoral Overview of Public Policies in Cameroon's Forests since 1960. A draft report - part of $\mathrm{ahD}$ thesis on tropical forest policies at the Institut d'Études Politiques and CIRAD, France.

Stewart KM. 2001. The commercial bark harvest of the African cherry (Prunus africana) on Mount Oku, Cameroun: Effects of traditional uses and population's dynamics. [PhD thesis]. Florida, USA: Florida international University.

Sunderland, TCH, Blackmore PC, Ndam N and Nkefor JP. 2002. The conservation through cultivation programme at the Limbe Botanic Garden. In Maunder M, Clubbe C, Hankamer $\mathrm{C}$ and Groves M, eds. Plant Conservation in the Tropics: Perspectives and Practice. Royal Botanic Gardens, Kew. 398-419. 
Sunderland T and Tako C. 1999. The exploitation of Prunus africana on the island of Bioko, Equatorial Guinea. Report for the People and Plants Initiative, WWF-Germany and the IUCN/SSC Medicinal Plant Specialist Group.

Tassé BD. 2006. Impact écologique de l'exploitation de l'écorce de Prunus africana (Hook. F.) Kalkman dans la région du Mont Cameroun: Cas de la zone Bokwango-Mapanja. Mémoire d'Ingénieur des Eaux, Forêts et Chasse, Université de Dschang, Cameroun.

Tchoundjeu Z, Avana ML, Leakey RRB, Simons AJ, Assah E, Duguma B and Bell JM. 2002. Vegetative propagation of Prunus africana: Effects of rooting medium, auxin concentrations and leaf area. Agroforestry Systems 54(3):183-92.

Towé J and Abonge B. 1997. Proceedings of a workshop on capacity building for Mapanja Prunus Harvester Union. MCP Limbé and Mapanja Prunus Harvester Union.

United Republic of Cameroon. 1976. Fourth Five-Year Economic, Social and Cultural
Development Plan (1976-1981). Yaoundé, Ministry of Economic Affairs and Planning. Vinceti B, Loo J, Gaisberger H, van Zonneveld MJ, Schueler S, Konrad H, Kadu CAC and Geburek T. 2013. Conservation priorities for Prunus africana defined with the aid of spatial analysis of genetic data and climatic variables. PLoS ONE 8(3): e59987. doi:10.1371/journal. pone.0059987

Walter S and Rakotonirina JR. 1995. L'exploitation de Prunus africana á Madagascar. PCDI Zahamena et la Direction des Eaux et Forets, Antananarivo, Madagascar.

Wazinski R. 2001. Untersuchungen kultivieter Prunus africana in der nord-west und süd-west provinz kameruns unter ökologischen und sozio-ökonomischen aspekten. Universität Hamburg, Germany.

[WCMC] World Conservation Monitoring Centre. 1998. Prunus africana. The IUCN Red List of Threatened Species. Version 2014.2. Accessed 9 August 2014. www.iucnredlist.org 


CIFOR Working Papers contain preliminary or advance research results on tropical forest issues that need to be published in a timely manner to inform and promote discussion. This content has been internally reviewed but has not undergone external peer review.

After 42 years of international trade in wild harvested medicinal bark from Africa and Madagascar, the example of Prunus africana holds several lessons for both policy and practice in forestry, conservation and rural development. Due to recent CITES restrictions on $P$. africana exports from Burundi, Kenya and Madagascar, coupled with the lifting of the 2007 EU ban in 2011, Cameroon's share of the global $P$. africana bark trade has risen from an average of 38\% between 1995 and 2004, to $72.6 \%$ (658.6 (metric tons or $\mathrm{t}$ )) in 2012. Cameroon is therefore at the center of this international policy arena. First, despite the need to conserve genetically and chemically diverse $P$. africana, there are no populations in Cameroon that are completely protected. Commercial harvesting is allowed in Mount Cameroon National Park (MCNP) and enforcement within forest reserves such as Nkom-Wum Forest Reserve, Mount Manengouba is limited. Second, hopes of decentralized governance of this forest product are misplaced due to elite capture, concentration of power and "informal taxation" (bribery). Although shifts away from an export monopoly did occur, this resulted in "resource mining" rather than the intended sustainable resource management after 1987, when 50 Cameroonian entrepreneurs entered the bark trade. In 2004, this halved to 25 companies. In 2007, just nine companies received quotas, only one of which (Afrimed) actually exported bark. Afrimed continues to dominate the export trade to date. As one of four companies under the umbrella of a privately owned Cameroonian bank, Afrimed is different to other exporters in terms of power and influence. At the current European price for P. africana bark (USD 6 per kg), the 2012 bark quota ( $658.675 \mathrm{t}$ ) was worth over USD 3.9 million, most of it accruing to Afrimed. Third, in contrast to lucrative bark exports, livelihood benefits to local harvesters from wild harvests are low. For example, the 48 harvesters working within MCNP receive less than USD 1 per day from bark harvests, due to a net bark price of just USD 0.33 per $\mathrm{kg}$ (or $43 \%$ of the farm-gate price for wild harvested bark). The costs of maintaining an inventory, monitoring and managing sustainable wild harvests are far greater than the benefits to harvesters. Without the current substantial international donor subsidies, sustainable harvest cannot be sustained. To supply the current and future market, we must develop separate, traceable $P$. africana bark supply chains based on cultivated stocks. More Cameroonian small-scale farmers cultivate $P$. africana than farmers in any other country. This change requires CITES and EU support and would catalyze $P$. africana cultivation in Cameroon, doubling farm-gate prices to harvesters - from the current FCFA 150 per kg (USD 0.33) received by wild bark harvesters to FCFA 294 per kg (USD 0.66 ) - that could be paid to farmers after a $15 \%$ traceability cost was deducted.

\section{RESEARCH}

PROGRAM ON

Forests, Trees and

Agroforestry
This research was carried out by CIFOR as part of the CGIAR Research Program on Forests, Trees and Agroforestry (CRP-FTA). This collaborative program aims to enhance the management and use of forests, agroforestry and tree genetic resources across the landscape from forests to farms. CIFOR leads CRP-FTA in partnership with Bioversity International, CATIE, CIRAD, the International Center for Tropical Agriculture and the World Agroforestry Centre.

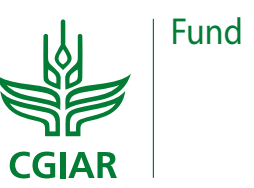

